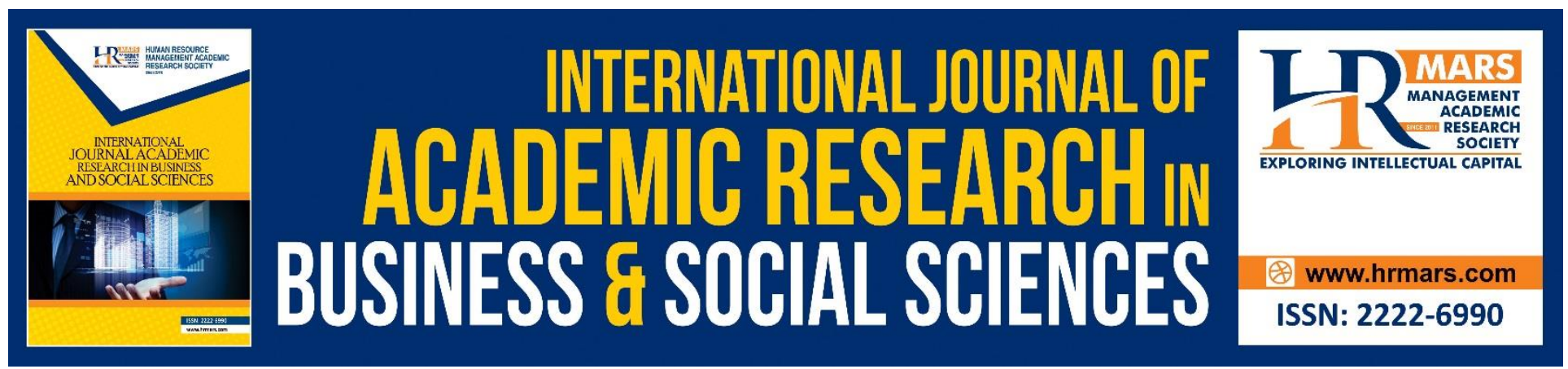

\title{
Conflict Management in the Constitution of Medina: An Analysis
}

\section{Zaleha Embong}

To Link this Article: http://dx.doi.org/10.6007/IJARBSS/v8-i12/5041

DOI: $10.6007 /$ IJARBSS/v8-i12/5041

Received: 21 Oct 2018, Revised: 01 Dec 2018, Accepted: 19 Dec 2018

Published Online: 26 Dec 2018

In-Text Citation: (Embong, 2018)

To Cite this Article: Embong, Z. (2018). Conflict Management in the Constitution of Medina: An Analysis. International Journal of Academic Research in Business and Social Sciences, 8(12), 396-414.

Copyright: (C) 2018 The Author(s)

Published by Human Resource Management Academic Research Society (www.hrmars.com)

This article is published under the Creative Commons Attribution (CC BY 4.0) license. Anyone may reproduce, distribute, translate and create derivative works of this article (for both commercial and non-commercial purposes), subject to full attribution to the original publication and authors. The full terms of this license may be seen

at: http://creativecommons.org/licences/by/4.0/legalcode

Vol. 8, No. 12, 2018, Pg. 396 - 414

http://hrmars.com/index.php/pages/detail/IJARBSS

JOURNAL HOMEPAGE

Full Terms \& Conditions of access and use can be found at http://hrmars.com/index.php/pages/detail/publication-ethics 


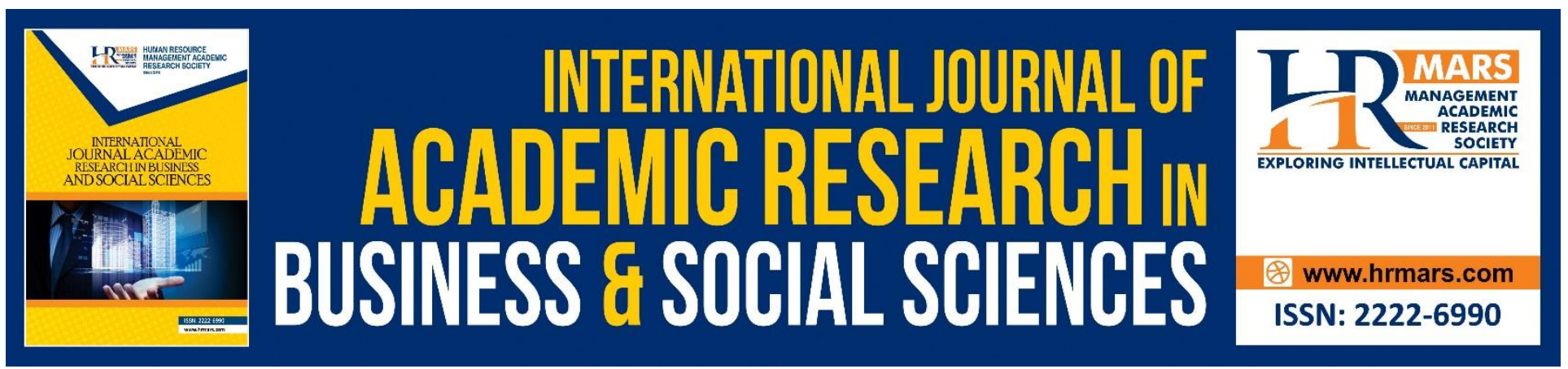

\title{
Conflict Management in the Constitution of Medina: An Analysis
}

\author{
Zaleha Embong \\ Center for Language Studies and Generic Development, Universiti Malaysia Kelantan \\ Email: zaleha.e@umk.edu.my
}

\begin{abstract}
Society which consists of diverse social backgrounds is vulnerable to conflicts. This causes issues like, discrimination, dispute, war, oppresion and other issues. Hence, conflict management plays an important role to control plural society. For instance, looking back through history, conflict, dispute and war usually occur in Medina as a result of differences of background and, tribal issues As the head of state, Prophet Muhammad PBUH, has promulgated The Constitution of Medina in order to manage and cater to the need of the citizens which comprise of diverse races, languages, religions, cultures and customs. The Constitution of Medina is the world's first written Constitution that successfully manages a plural society, making Medina a strong and respected country. Thus, this paper aims to identify and analyse the management of conflict in Medina. This paper uses data collection method through library research as well as in-depth interview. Meanwhile, content analysis method is used to analyse the data obtained. Findings revealed that Prophet Muhammad PBUH has successfully managed the plural society through clauses contained in The Constitution of Medina. Plural society is recognised as one nation (ummah) and it has created multiple ties for the sake of defending Medina from external threats.
\end{abstract}

Keywords: Conflict Management, Plural Society, The Constituition of Medina

\section{Introduction}

Human beings are created differently in terms of religion, race, language, culture, custom and other aspects, in order for them to mutually recognise and help each other. It is stated in surah al-Hujurat verse 13 which indicates:

"O mankind, we have created you from male and female and we made you with a variety of races and tribes, so that you may know each other. Indeed, the most righteous of you in the sight of Allah, is those who are pious. Surely, Allah is AllKnowing, the most Profound Knowledge ". 
According to Hamka (1985: 208), this verse elucidates that Allah SWT has created mankind from various nations and tribes, in order for them to acknowledge each other. Humans are encouraged to identify their origin, ancestors's origin, descendants and others. Glory in the sight of Allah is the glory of heart and soul, moral character and piety to Allah SWT. This verse is revealed with the aim to guide those who consider themselves to be superior to others. This is in line with the view of Ibn Katsir (2004:495-497), the creation of various human races and tribes is to ensure that humans can recognise each other. On the other hand, according to Osman (1997:121), this verse in particular, illustarates the basis of pluralism for humans to avoid conflicts and isolation. Meanwhile, diversity can encourage interaction, cooperation and human beings can complement each other.

Nevertheless, in reality, pluralism can actually cause discrimination, dispute and war. This happens in many countries comprising plural society such as, Myanmar, Sri Lanka, India, Syria, Palestin and so on. Community becomes victim of murder, rape, persecution, violation of human rights and others.

In the context of ancient Medina, there were a lot of wars and disputes among plural society because people were very protective and defensive of their respective tribes. Prophet Muhammad PBUH's migration from Makkah to Medina has led to a new beginning for all the communities in Medina. The arrival of Islam has changed their lifestyles. Prophet Muhammad PBUH, as the leader of the nation, has promulgated The Constitution of Medina to manage and enhance cooperation in the plural society.

\section{Medina's Society Before The Advent of Islam}

Discussion of communities of Medina before and after the arrival of Islam should be emphasised, as to acknowledge extreme changes of lifestyles. According to Wat (1956), knowledge of the condition in Medina, prior to the arrival of Islam is absolutely significant to capture and generate ideas of conditions or situations before and after the arrival of Prophet Muhammad PBUH in Medina. Before the arrival of Islam, disputes and battles between plural society often happened but, after the advent of Islam, the practice of cooperation has formed and enhanced the foundation of relationships between the communities of Medina (Siddiqi, 1982).

Arab society before the arrival of Islam, in particular, those who reside in the land of Hijjaz have a social structure that govern behavior patterns, family relationships and societies (Pulungan, 1993). The land of Hijjaz is a barren area which is a part of Jazirah Arab, located in between Nejd plateau and district of coastal Thimamah. There are three main cities which are Taif, Makkah and Medina. Its residents consist of Arabs and Jews. The Arabs live in Mecca, Medina and Taif while the Jews reside in Medina and other surrounding areas. The two roots are originally from ras Semit which begin from Prophet Ibrahim a.s. through his two sons, Prophet Ishak a.s. and Prophet Ismail a.s. Arab's root is through Prophet Ismail a.s. while Jewish's root is through Prophet Ishak a.s. (Guillaume, 2004).

Medina is a small town and its residents are estimated to be in between 4000 to 5000 people (Rahman, 1995:34). In terms of politics, Medina never has a systematic town planning because, it only focuses on racial issues (Rahman, 1992). Meanwhile, its social structure is based on tribal system 
INTERNATIONAL JOURNAL OF ACADEMIC RESEARCH IN BUSINESS AND SOCIAL SCIENCES Vol. 8, No. 12, Dec, 2018, E-ISSN: 2222-6990 C 2018 HRMARS

where every tribe protects and defends its own members (Al-Hamidi, 2006:151). There are also those who lead a nomadic way of life and they are known as Bedouins (Misrawi, 2011:108; Siddiqi, 1982:14).

At that time, Medinans are consisted of diverse races, tribes and clans. For example, the Arabs have different tribes, like Aus and Khazraj which are migrants from Southern Arabia while other tribes reside in Medina (Ali, 1982). Ibn Sa'dal-Baghdadi clarifies that, from the two large tribes of Aus and Khazraj, there are eight clans as well as 33 other smaller groups, as stated in The Constitution of Medina, which have faught together in the Battle of Badr (Watt, 1956:153). The Arabs believe in superstition, they worship false God or they are the idol worshipers ${ }^{1}$ and they proclaim to the religion of Jewish and Christian. Meanwhile, the Jewish who subscribes to the teachings of Prophet Musa a.s is estimated to account to a total number of 20 tribes and the three most well known among the tribes are Bani Quraizah, Bani Nadhir and Bani Qainuqa'(Mat Saad Abd. Rahman, 1995:34; J. Suyuthi Pulungan, 1993:39). ${ }^{2}$ Every group resides in specific areas and they rarely interact within the plural society. Hence, disputes and fights often occur among them (Misrawi, 2011).

Medinans have their own way of life and they have a social tie or structure which separates them from one tribe to another. At that particular time, the relationships between Arabs and Jews were chaotic because each of the tribe demanded to conquer and lead Medina. Besides that, those Jews themselves were enemies within their large communities (An-Nadwy, 1983). Jewish controlled and was influential in the economic sector of Medina. ${ }^{3}$ They practised usury and mortgage or loan. Mortgage was used not only for trading of goods but, it also included women and children. They made a lot of profits and this created hatred towards Jews by the Arabs (Al Mubarakfuri, 2011; Misrawi, 2011; An-Nadwy, 1983).

\footnotetext{
${ }^{1}$ The Arabs follow Quraisy's principles in the aspects of akidah and belief. They believe that the tribes of Quraisy are religious leaders and guardians of Baitullah (Kaabah). Medinans worship idols, similar to the way Quraisy people worship idols. However, Medinans glorify the statue of Manat, difference from those Quraisy who glorify the statue of al-Uzza (An-Nadwy, 1983).

${ }^{2}$ These three tribes have caused the battle between the tribe of Aus and Khazraj for ages. As an example, the battle of Bu'ath which occured in 619 B.C, caused by Jewish's plans which aimed to divide the Arabs who have conquered Medina since the Sixth Century B.C (Al Mubarakfuri, 2011; Rahman, 1995; An-Nadwy, 1983). Apart from that, Bani Qainuqa' betrayed the Constitution of Medina by degrading Muslims' victory in the battle of Badr, on 17 Ramadhan, in the second year of Hijrah. Their village was guarded and they were forced to evacuate from Medina in the year $2 \mathrm{H}$. Bani Nadhir was driven out from Medina in the year $4 \mathrm{H}$ because they supported the Quraisy in the battle of Uhud and they created an ally to kill Prophet Muhammad PBUH. Meanwhile, Bani Quraizah was given a harsher punishment: all male adults were killed and their properties were confiscated, women and children were driven out of Medina in the year $5 \mathrm{H}$. They breached the agreement as they helped Quraisy in the battle of Khandak by allowing the enemies to attack Muslims from their place of residents (Pulungan, 1993). Allah SWT states the rescission of the collaboration with the three Jewish tribes in surah al-Anfal verse 58 which means:
}

"If you (Muhammad), have reasons to fear the betrayal of certain group of people, give their treaty back with honesty and truth. Indeed, Allah does not like traitors."

According to Watt (1956), this expulsion was based on a valid reason to ensure peace and harmony in Medina. After the expulsion of the three major Jewish tribes, other Jews were still living in Medina. Some of them who were included in the Constitution of Medina were, Bani 'Auf, Bani al-Najjar, Bani Saidah, Bani al-Harith, Bani Jusyaim, Bani al-Aus, Bani Shutaibah, Bani Tha 'labah and Bani Jafnah (Rahman, 1995; Barakat, 1979). One by one of the Jewish tribes are stated in the Consitution of Medina as they are from various groups. This portrays that Jewish does not join Medina as a unit of society but, as a separate unit. If Muslims fight against certain Jewish tribes or impose them to leave Medina, other tribes choose to be silent. In fact, they also provide military help to Muslims (Ibrahim \& El-Qasimy, 1985:12-13).

${ }^{3}$ At the time of Prophet Muhammad PBUH's migration, the position of Jews has been declining and the position of Arabs strengthens. Every business which is led by Arabs and their unions becomes stronger and powerful until Jews cannot divide their unions (An-Nadwy, 1983). 
INTERNATIONAL JOURNAL OF ACADEMIC RESEARCH IN BUSINESS AND SOCIAL SCIENCES

Vol. 8, No. 12, Dec, 2018, E-ISSN: 2222-6990 @ 2018 HRMARS

\section{Medina's Society After The Advent of Islam}

The Messenger of Allah, PBUH, arrived in Medina among Bani al-Najjar, on Friday, 12 Rabiulawal, the first year of Hijrah which is equal to, 27 September, 622 B.C. He visited the house of Abu Ayub alAnsari (Al Mubarakfuri, 2011; Al-Buthy, 2006).

His visit was well celebrated by Medinans, unlike Makkans who were opposed to Islamic teachings (Misrawi, 2011:110; Rahman, 1992). This is because Arabs who are originaly from Medina, understand and acknowledge divinity and prophethood as they mingle with the Jews who profess their faith to the teachings of Prophet Musa a.s.. In addition, the Jews always remind them regarding the ressurection of a prophet and messenger (Rahman, 1995:35).

This migration has changed the composition of residents in Medina ${ }^{4}$ to become three large clusters which are immigrant Arabs from Makkah who migrate together with the Prophet PBUH, Arabs from Medina and Jewish. Arabs from Makkah who are Muslims, are known as Muhajirin while those Muslims who are from Medina, are known as Ansar ${ }^{5}$. On the other hand, the non-Muslims are accumulated by two different groups which are Jewish and idol worshippers who are known as wathaniyyin (Ahmad, 1973; Abd. Rahman, 1995:36)

In Medina, Prophet Muhammad PBUH has amended some important changes for the sake of improving the social structure within those societies. Among the steps taken are (Sungib, 2013:133136; Al-Buti, 1997; Rahman, 1992; Al-Siba'ei, 1985; Siddiqui, 1975):

\section{The building of Mosque}

Masjid Quba' is the very first mosque which is built by the Messenger of Allah. The mosque was built when he visited Quba' on 8 Rabiulawal before he arrived in Medina. It was built upon the foundation of faith and devotion towards Allah SWT.

In Islamic history, Masjid An-Nabawi is the second mosque which is built. The mosque is not only used for the purpose of worship but, as a place for discussion, administration, education, social and other activities. Furthermore, it becomes the place for consultation and it strengthens the bond within Muslim community (Al-Mubarakfuri, 2011; Siddiqui, 1975; Al-Siba'ei, 1985). The mosque also becomes the meeting place among Muslims and the Messenger of Allah in order to learn Islamic teachings and social rules or etiquettes (Rahman, 1992).

\section{Amalgamation or integration of Muslims as Brothers}

After the building of mosque, the Messenger of Allas has amalgamated all Muslims as brothers so that they will help each other and have strong brotherhood between Muslims (Sungib, 2013) ${ }^{6}$. This is in accordance with the words of Allah SWT in surah al-Anfal verse 72 which means:

\footnotetext{
${ }^{4}$ There are a lot of opinions regarding the composition of Medinans after the migration of the Apostle of Allah. As an example, Hasan Ibrahim Hasan and Emile Dermenghem suggest that Medinans consist of Muhajirin, Ansar, Atheist and Medinan's Jews. In contrast, Khadduri, Kerk and Shalaby believe that Medinans are made up of Muhajirin, Ansar and Jews (as cited from Ahmad, 1973). ${ }^{5}$ Ansar has helped the Apostle of Allah and Muhajirin during their migration. Their helps are fundamental in the development of Islam. The term 'Ansar'
itself denotes helper, safeguarder, protector and others (Hamka, 1985d). The Apostle of Allah loves Ansar as narrated by Anas r.a., The Apostle of Allah
mentions, which means:
}

"Sign of faith is, loving the Ansar while sign of hypocrricy is, hating the Ansar.".

(Bukhari, No. 12)

${ }^{6}$ Ibn al-Qayyim has recorded an event in his note that "the Apostle of Allah has united Muhajirin and Ansar in a ceremony at the house of Anas bin Malik. 90 men, half of them are Ansar and half of them are Muhajirin, attend the ceremony. The Apostle of Allah makes them brothers so that they may 
"Verily, believers and those who migrate as well as engaging in jihad (crusade or holy war) with all their wealth and soul for the sake of Allah SWT, and, those who provide shelter and help (to Muhajirin), they are those who protect one another."

As delineated by the Apostle of Allah, which indicates,

"Narrated by Abu Musa r.a., indeed, a believer to another believer is like a building which strengthens each other. While mentioning this hadith, the Messenger PBUH intersects his fingers".

(Bukhari, No. 285)

The union of Muslims by the Prophet PBUH comprises of the union between Ansar with Muhajirin and Muhajirin with Muhajirin. ${ }^{7}$ The union of Muhajirin consists of Muhajirin of higher status with those from the lower ones. This is for the sake of abolishing social difference or hierachy which is practised among Quraisy jahiliah where each of the tribe is given a different position or status. In addition, the union among Ansar consists of tribes of Aus and Khazraj. This is to ensure ukhuwah islamiah ${ }^{8}$ among Muslims (Sungib, 2013:134). Implication of the union is revealed by Allah SWT in surah al-Hasyr verse 9 which designates:

"They (Ansar) have resided in Medina and they have their own faith before the arrival of them (Muhajirin), they love those who migrate to their place. And, in their hearts, they never hope to accumulate what is provided to them (Muhajirin). And they prioritise Muhajirin more than their own self even when they are in needs".

Al-Ghazaliy (1997) mentions that, this brotherhood aims to eliminate 'asabiyyah jahiliah and differences which are based on hereditary. It brings changes to the society as people are willing to sacrifice their wealth.

3. The promulgation of the Constitution of Medina which is a treaty between Muslims and nonMuslims.

Medina consists of plural society which needs a treaty to build a good relationship within the plural society. Hence, the Messenger of Allah has outlined a few things which should be emphasised (Ibrahim \& El-Qasimy, 1985:9):

i. Justification of right and responsibility among Muslims as well as other Medinans.

ii. Glorification of Muslims who migrate.

iii. Comprehension of non-Muslim communities especially the Jews.

iv. Organisation of political system and defense in Medina.

help each other and they can inherit property. Then, came surah al-Anfal verse 75 which gives the rights of inheritance to those who have rights based on Islamic shari'a and not based on the ties between Muslims" (as cited from Al-Mubarakfuri, 2011:247).

\footnotetext{
${ }^{7}$ He has united Muhajirin with Ansar, Ja‘afar bin Abi Talib with Muaz bin Jabal, Abu Bakar Al-Siddiq with Kharijah bin Zaid, Umar bin Al-Khattab with Itban bin Malik, Abdul Rahman bin Auf with Sa'ad bin Ar-Rabi', Abu Ubaydah Al-Jarrah with Sa'ad bin Muaz, Mus'ab bin Umayr with Abu Ayyub Al-Ansari and so on. After that, the Apostle of Allah, PBUH, has united Muhajirin among Muhajirin, Hamzah bin Abdul Muttalib with Zaid bin Harithah, Zubir bin Al-Awwam with Abdullah bin Mas'ud, the Apostle of Allah with Ali bin Abi Talib and so on (Al-Buti, 1997:280; Hamka, 1985d:66; Sungib, 2013:146; Yusoff \& Rahman, 2004).

${ }^{8}$ In Ensiklopedia Istilah Agama Islam, ukhuwah islamiah means Muslims brotherhood. This is mentioned in al-Qur'an, such as, surah al-Baqara verse 220, Ali 'Imran verse 103, al-Ahzab verse 5 and al-Hujurat verse 10. Muslims brotherhood is created within the foundation of religion, faith and submission to Allah SWT. The unification of Muslims is bounded with certain values like, the spirit of being helpful to one another, mutual respect, equal rights and reponsibilities, love and others. In fact, ukhuwah islamiah does not justify human beings within the context of racial difference, ancestry, colour, status and wealth (Sosrodirdjo, 1988:159). Khaldun (2006) explains the importance of ukhuwah and cooperation in religious movement. Islamic movement will not succeed without strong ukhuwah (bonds) within societies.
} 
INTERNATIONAL JOURNAL OF ACADEMIC RESEARCH IN BUSINESS AND SOCIAL SCIENCES Vol. 8, No. 12, Dec, 2018, E-ISSN: 2222-6990 @ 2018 HRMARS

v. Compensation of loss, loss of life and property which are experienced by Muhajirin and caused by Quraisy.

Thus, the Messenger of Allah has made an agreement between Muslims and non-Muslims in Medina. According to Ishaq (1970), the Messenger of Allah has written a constitution or treaty which is known as the Constitution of Medina and it describes the relationhip between Muhajirin and Ansar as well as agreement with the Jews. This agreement outlines collective responsibilities among each group to defend the country. For instance, Jewish tribes which are included in the Constitution of Medina, are, Bani 'Auf, Bani al-Najjar, Bani al-Harith, Bani Saidah, Bani Jusyaim, Bani al-Aus, Bani Tha'labah, Bani Jafnah and Bani Shutaibah. On the other hand, Muslims from Medina compromise of Bani Auf, Bani al-Harith, Bani Sa'idah, Bani Jusyam, Bani al-Najjar, Bani 'Amru bin 'Auf, Bani al-Nabiet and Bani Aus.

\section{The Amendment of The Constitution of Medina}

The Constitution of Medina is written completely by two Muslim writers, Ibn Ishaq (Wafat $151 \mathrm{H})$ and Ibn Hisyam (Wafat 213H) (Izzuddin, 2008:110). This constitution is the very first written consitution in the world, which is formulated by Prophet Muhammad PBUH as a guide to the plural society in Medina (Watt, 1956; Hamidullah, 1968; Ahmad, 1973; Rahman, 1992; Sidek, 2004; Ibrahim \& ElQasimy, 1985). According to Watt (1956), Peters (1994) and Khairuddin (2007), The Consitution of Medina is an authentic document and it provides a suitable content within the context of sociological and historical value of that particular era. Guillame (2004) name the Constitution of Medina as Friendly Agreement in his book, The Life of Muhammad. According to Guillame (2004), the constitution upholds togetherness between Muhajirin and Ansar as well as Jewish. These group respect each other's religious belief and protect each other's rights and they have mutual responsibilities to defend Medina. Ishaq suggests that (as cited from Peters, 1994:198):

"And the Apostle of God wrote document between the Migrants and the Helpers and in it he made a peace (wada'a) with the Jews and the pact ('ahada) with them and he confirmed them according to their religion/law ('ala dinihim) and properties and laid down obligations due to them and imposed obligations upon them".

It is clear that the promulgation of the constitution of Medina aims to organise relationships and to solve problems among plural society in Medina. Moreover, the constitution of Medina was completed in the first and second year of Hijrah. It constitutes 47 Clause which are divided into two sections. ${ }^{9}$ The first section includes Clause 1 until Clause 23 which emphasise the relationship between Muhajirin and Ansar and, they are completed before the Battle of Badr while Clause 24 until Clause 47 are related to rights and responsibilities among Jewish and they are completed after the Battle of Badr (Rahman, 1995:38; Hussin, 2003). The Constitution of Medina is the strategy of the Apostle of Allah to organise political system and social structure in Medina. This is because Medina

\footnotetext{
${ }^{9}$ In the original text of the Constitution of Medina, there is no division of Clause. The division of 47 Clauses is used by Wensinck in his research, Mohammed en de Joden te Madina in 1928 B.C which is written for his doctoral degree in Semite Literature (Watt, 1956; Izzuddin, 2008:111). Nevertheless, Hamidullah (1968) believes that the Constitution of Medina consists of 52 Clauses: the first part accumulates 25 Clauses while the second one includes another 27 Clauses. Generally, historians recorded that the constitution was written in the first year of Hijrah (Ibrahim \& El-Qasimy, 1985). On the other hand, Hamidullah (1968) has given the possibility that the first part was written in the first year of Hijrah and the second part was written later, after the Battle of Badr.
} 
needs a new administration system which is systematic to manage it's plural society as well as to strengthen itself in order to face various threats.

Apart from that, the Constitution of Medina justifies complexities and questions like, rights and responsibilities of rulers as well as those who are ruled, jurisprudence, justice, the structure of defense, the position of the sole leader, treatments to non-Muslims, the assurance of social and the definition of ummah (nation) (Ibrahim \& El-Qasimy, 1985). According to Che Bakar Che Mat et al. (2007:27), there are nine major components of the Constitution of Medina which are, the formation of ummah, human's right, Islamic society, the union of every citizen, minority group, citizens' reponsibility, country's protection, leadership and assurance of harmony In the constitution or treaty, the Messenger of Allah adopts the principle of toleration, responsibility, justice, love and respect in order to manage the pural society in Medina. This shows his determination in establishing harmony under Islamic ruling. ${ }^{10}$ Clauses in the Constitution of Medina are as shown in Table 4.

\section{Conflict Management in the Constitution of Medina}

Muslim scholars like, Ibn Abi Rabi', Al-Mawardi, Al-Ghazali and Ibn Khaldun think that, a systematic society is needed to create an environment that is peaceful and harmony. This needs a competent leader to execute it properly (Pulungan, 1993; Khaldun, 1993). The Messenger of Allah has succeded in managing the conflict among plural society through the promulgation and amendment of the Constitution of Medina. As stated by Rafiq (2009), this constitution is a model which is manifested from the Holy Quran and later, translated into real life. Therefore, this constitution features a comprehensive reign which meets the need of plural society. Majid argues that: ${ }^{11}$

"Medina is built and founded through cooperation between races.".

This is because the Messenger of Allah recognises Muslims and non-Muslims as citizens through the concept of ummah (nation). ${ }^{12}$ (Watt, 1956; Al-Ghazaly, 1997; Izzuddin, 2008). The Messenger of Allah declares the concept of ummah in respective Clause :

Clause 2:

"That they are one ummah (bangsa/nation) different from other human beings". Clause 25:

"That Jews from Bani 'Auf are one ummah, together with the rightheous. They are free to practise their own religious beliefs. Muslims, with their own religion as well as those who associate with them and, they themselves. Except those who are cruel and those who are sinful. Hence, it will not affect himself and his own family".

Clause 25 until 34, Jewish tribes are mentioned one by one in order to explain their position as one ummah (nation), together with Muslims. According to Al-Buti (1997), the implementation of ummah has succeeded in curbing caste system which disrupt social system. Ibrahim and El-Qasimy (1985), clarify that the Constitution of Medina recognise Jews as citizens of Medina as along as they perform

\footnotetext{
${ }^{10}$ Interview with Al-Bakri at Pejabat Pustaka Cahaya Kasturi, Putra Nilai, Nilai, Negeri Sembilan on 29 January 2013.

${ }^{11}$ Interview with Majid at Department of Fiqh and Usul Fiqh, Kulliyyah Islamic Revealed Knowledge and Human Sciences, UIAM, Gombak on 30 January 2013.

${ }^{12}$ According to Watt (1956), the word, ummah originates from Ibrani which means national tribes or communities. Meanwhile, Yaacob (1986) believes that in the context of nationality, ummah (nation) means society or citizen. In al-Qur'an, the word ummah is mentioned for 52 times which are deliberated in various verses (as cited from Izzuddin, 2008:114).
} 
INTERNATIONAL JOURNAL OF ACADEMIC RESEARCH IN BUSINESS AND SOCIAL SCIENCES Vol. 8, No. 12, Dec, 2018, E-ISSN: 2222-6990 @ 2018 HRMARS

their responsibilities. Nevertheless, there are three major Jewish tribes, Bani Quraizah, Bani Nadhir and Bani Qainuqa' which have violated the rules and they are evicted from Medina. Bani Qainuqa' has first betrayed Muslims and disobeyed the rules of the treaty until their cooperation has been cancelled. ${ }^{13}$ According to Majid, that:

"If Jews do not disobey and betray, the treaty will still continue".

Therefore, the Messenger of Allah makes Medinans as one ummah, so that, the society respects, tolerates and everyone is responsible to establish Medina as a harmonious country. The implementation of the concept of ummah has also built love and justice among society. This shows that the Messenger of Allah practises certain principles like, tolerance, love, respect, justice and responsibility in the Constitution of Medina. These principles will be discussed further in order to examine Prophet Muhammad PBUH's success in managing conflicts among plural society in Medina.

\section{The Principle of Tolerance}

The principle of tolerance has been discussed thoroughly in the Holy Quran, whether literally or metaphorically. ${ }^{14}$ Quran explains the principle of tolerance to human beings, so that they can accept differences, respect and execute justice. Allah SWT mentions surah al-Ma'idat verse 8 which indicates:

"O believers! Stand-up firmly by the commandments of Allah SWT, bearing witness

with justice and let not the enmity or hatred towards any race incite you that you

should not do justice. Do justice as it is nearer to piety and fear Allah SWT,

undoubtedly, Allah SWT is aware of your doings".

Hence, the Messenger of Allah implements the principle of tolerance in order to enhance equality and social (Mat \& Suradi, 2012). Based on opinions of Majid:

"The practice of tolerance between Muslims and Jews has created equal right and

responsibility among all parties".

Thus, religious freedom for every citizen is implemented in the Constitution of Medina (Sidik, 2004). Al-Mubarakfuri (2011:256) and Al-Ghazaliy (1997) declare that, the Messenger of Allah outlines rules which justify the principle of tolerance which is never used by other leaders before. Al-Bakri states that: ${ }^{15}$

"Non-Muslims are given religious freedom because Islam acknowledges human's diversity".

\footnotetext{
${ }^{13}$ Ishaq (1970) narrates that the Messenger of Allah gathers the tribe of Bani Qainuqa' at Qainuqa' market, then, he gives a speech: "Oh Jews, beware of Allah SWT as He can give punishment to the descendants of Quraisy. Revert to Islam. You know that I am the Messenger of Allah SWT, as written in your scripture and Allah's promise to you". They answer: "Oh Muhammad, are you telling lies to us, just like what your descendants did to us? You cannot believe in lies, it is true that you are challenging a tribe which do not have experinces in battles. Thus, you have the chance to change them. Indeed, in the name of Allah, if you want to try and to get to know who we are and our types, you can do so". This event occurs when a Jew has disrupted a woman's dignity or chastity at Qainuqa' market. Hence, Muslims and Bani Qainuqa' fight one another. This event marks the very first dispute among them after the agreement between the Apostle of Allah SWT and Jews. The fight occurs as narrated by Al-Tabari and Al-Waqidi, in the middle of Syawal, the second year of Hijrah (Al-Buti, 1997).

${ }^{14}$ Among them are, surah al-Baqarat verse 190 and 256, al-Nisa' verse 58, al-Ma'idat verse 5, al-Hajj verse 39-40, al-Anfal verse 57-58, Yunus verse 99, al-Mumtahanah verse 9, al-'Ankabut verse 46 and others.
}

${ }^{15}$ Interview with Al-Bakri at Pejabat Pustaka Cahaya Kasturi, Putra Nilai, Nilai, Negeri Sembilan on 29 January 2013. 
Arnold (1913) believes that, the Messenger of Allah allows freedom of religion and protects the place of worships for Christians and Jews. The principle of tolerance encourages plural society to respect and cooperate with each other. According to Al-Bakri, the principle of tolearance is written in Clause 25 which mentions: ${ }^{16}$

"That Jews from Bani 'Auf are one ummah, together with the rightheous. They are free to practise their own religious beliefs. Muslims, with their own religion as well as those who associate with them and, they themselves. Except those who are cruel and those who are sinful. Hence, it will not affect himself and his own family".

This Clause is in sequence with Clause 26, 27, 28, 29, 30, 31, 32, 33, 34 and 35 which explains the freedom of religion which is given to non-muslims. In these clauses, Jewish tribes are mentioned one by one in order to explain their roles and reponsibilities as citizens of Medina. Jewish tribes which are recorded in the Constitution of Medina are, Bani 'Auf,Bani al-Najjar, Bani al-Harith, Bani Saidah, Bani Jusyaim, Bani al-Aus, Bani Tha'labah, Bani Jafnah and Bani Shutaibah. These Clauses specify that Jews and Muslims are one ummah (nation). Majid believes that the concept of ummah (nation) is related with political cooperation and it is not included in religious issues. ${ }^{17}$ This shows tolerance among leaders when Medina as an Islamic country becomes proprietary among community of different religious beliefs and Medina does not exclusively belong to Muslims (Khan, 2003).

Therefore, Misrawi (2011), Hussin (2003) and Al-Ghazaliy (1997) believe that, the Constitution of Medina is the Messenger of Allah's efforts in order to organise the society through the principle of tolerance. Not only that non-Muslims are given the freedom to practice their respective religion but, they are also provided with security and defense. This is stated in at-Tawbat verse $4^{18}$ and al-Anfal verse $61^{19}$ (Ibrahim \& El-Qasimy, 1985).

\section{The Principle of Love}

According to Al-Buti (1997:281-282), a particular country cannot stand tall without understanding and unity among society. Thus, the Constitution of Medina includes the principle of love which create unity in plural society (Khalid, 1994). This principle also strengthens Medina as mentioned by Al-Bakri:

"Medinans are bounded by love until they are willing to sacrifice for the sake of their brothers".

\footnotetext{
${ }^{16}$ ibid.

${ }^{17}$ Interview with Majid at Department of Usul Fiqh, Kulliyyah Islamic Revealed Knowledge and Human Sciences, UIAM, Gombak on 30 January 2013.

${ }^{18}$ Allah SWT denotes that:

"An exception is given to the hypocrites who etablish and agreement with you and stick to what they promise (the content of the agrrement) and they do not help your enemies. Thus, you should also submit to the agreement until it reaches the end. Indeed, Allah SWT loves the righteous".

${ }^{19}$ As revealed by Allah SWT which means:

"And if they support peace, therefore, you should also be supporting it as well as leaving everything to Allah SWT. Indeed, Allah is Hearing and Knowing".
} 
Meanwhile, Yusoff and Rahman (2004) state that, there is no event in history which showcases the same amount of love which is developed between Muhajirin and Ansar. Muhajirin and Ansar have a strong brotherhood that people of Ansar are willing to sacrifice their wealth or property and life as signs of love and Muslim's brotherhood. This is recounted by Abu Hurairah r.a. which denotes:

"People of Ansar say to Prophet PBUH: "Divide those palm trees between us and our brothers, people of Muhajirin. The Messenger of Allah mentions: "No!". Later, people of Ansar say to Muhajirin: "Pay us the cost of the maintenance and we divide the fruits". People of Muhajirin answer: "Alright, we agree".

\section{(Bukhari, No. 1132)}

Love as a virtue can be captured through an event where the Messenger of Allah's companion, Saad bin Rabi' (Ansar), is willing to give half of his property to Abdul Rahman bin Auf r.a. (Muhajirin). However, Abdul Rahman bin Auf r.a. declines his companion's property and ask him to give direction to the market so that he can start his business. Eventually, Abdul Rahman bin Auf r.a. becomes a rich man and a philanthropist (Jerlun, 1990:47).

Allah SWT explains the principle of love in surah al-Hasyr verse 9. Muslims and non-Muslims also respect and help each other. Every community has its own rights and similar positions in the Constitution of Medina. Therefore, Medina becomes a country which is peaceful and harmony (Sungib, 2013:445). Siddiqi (1982) suggests that, the reformation by the Messenger of Allah does not include any oppresion but, he instills the value of love and being considerate to others.

Thus, the principle of love can be seen within the Constitution of Medina, for example, in Clause 15. According to Yaacob (1986), every society should be responsible and cooperative in order to protect those who are weak regardless of race and religion. Denny (1977), on the other hand, believes that Clause 15 proves leader's attitude which is attentive because he provides equal protection as well as assurance from Allah SWT. Clause 15 describes that:

"Allah SWT's assurance is one and it is the same. Protecting the fate of those who are weak because of their own action. Mu'min should give assurance to one another, towards (disruption) of other people".

In addition, the principle of love is also included in Clause 16. The clause explains that Muslims should offer help to non-Muslims who have problems. According to Ibrahim and El-Qasimy (1985), Jews who are loyal to the country have their own rights to receive help. In fact, anyone cannot mistreat or torture them. Clause 16 states that:

"Jews who join us should receive help and leadership and they cannot be mistreated.

There should be no harmful alliance or conspiracy towards them".

Moreover, Clause 18 describes plural society's cooperation when facing any threat. This clause demonstrates that love exists, so that society takes care of one another. Hamid (2014) mentions, the Messenger of Allah's implementation of justice during his reign can be considered as a representation of love towards plural society. Clause 18 declares that:

"Every attack towards us should be reckoned as attack towards everyone. Therefore, we should alternate our energy together against it".

According to Sidik (2004), the principle of love exists in Muslims' relationship as highlighted in Clause 19. This clause clarifies the rights of brotherhood among Muslims' community. Thus, Muslims should be responsible in defending each other to strengthen their bonds. Clause 19 signifies that: 
"Mu'min must defend each other for every blood which is spilt in the path to Allah SWT".

Love as a principle which is included in these clauses have built cooperative relationship and social stability in plural society. ${ }^{20}$ This indicates that every member of societies which is included in the Constitution of Medina has given positive impacts and succeded in shaping cooperative relationship among plural society (Noor, 2010a).

\section{The Principle of Respect}

The Constitution of Medina also portrays respect as a virtue or value. The Messenger of Allah recognises Medinans as one ummah (nation) so that they respect each other and cooperate in order to defend or protect Medina. Muslims are not allowed to distrupt and neglect non-Muslims' rights (Al-Siba'ei, 1985). Al-Bakri points out that respect is outlined in the Constitution of Medina when every member of society's rights are recognised, as citizens of Medina. ${ }^{21}$

According to Majid, respect is formed between rulers and those who are ruled. Medinans recognise the Messenger of Allah as the sole leader of the country and he becomes the reference to any sort of problem. ${ }^{22}$ Similarly, Ahmad Ibrahim and El-Qasimy (1985) as well as Ali (1975) have the same opinions. Sidik (2004), Yaacob (1986) and Watt (1956) also think that when difference and argument occur, those problems should be solved in accordance to the laws of Allah SWT and the Messenger of Allah's decision. The Messenger of Allah has the highest authority and everyone will refer to him, as mentioned in Clause 23 and Clause 42. Clause 23 showcases that:

"No matter how strong you argue, you need to always refer to the Almighty and

Prophet Muhammad PBUH".

Meanwhile, Clause 42 highlights that:

"Whatever evil (murder) or any fight between members of the treaty, if it can lead to any threat or destruction, it should be refered to the jurisprudence of Allah SWT and solutions by Prophet Muhammad PBUH, the Messenger of Allah. Allah SWT approves the truthful contents of the treaty and He has given His blessings".

Apart from that, the principle is also seen in Clause 40 which clarifies society's obligations to protect and respect neighbours. Sidik (2004:107) believes, Clause 40 discusses every member of society's responsibilities towards his or her neighbours. According to Jusoh (1982) and Dollah (1978), Islam emphasises the importance of respecting neighbours and it is one of the factors to complete one's faith. Society should offer help and look after the security of its neighbourhood if problems occur. Clause 40 states that:

"Neighbours should be treated the way one treats his or her self and they cannot be treated with harmful things and sins".

Similar principle is mentioned in Clause 41 which vindicates women's rights and that they should be given respect. According to Che Mat et al. (2007), Islam recognises and provides nobility to women

\footnotetext{
${ }^{20}$ Interview with Al-Bakri at Pejabat Pustaka Cahaya Kasturi, Putra Nilai, Nilai, Negeri Sembilan on 29 January 2013.

${ }^{21}$ ibid.

${ }^{22}$ Interview with Majid at Department of Fiqh and Usul Fiqh, Kulliyyah Islamic Revealed Knowledge and Human Sciences, UIAM, Gombak on 30 January 2013.
} 
INTERNATIONAL JOURNAL OF ACADEMIC RESEARCH IN BUSINESS AND SOCIAL SCIENCES Vol. 8, No. 12, Dec, 2018, E-ISSN: 2222-6990 C 2018 HRMARS

by giving them protection and security. It is obligatory to protect women's dignity in any condition and it is prohibited to destroy or ruin women's digniy. Clause 41 signifies women's right:

"Woman's chastity cannot be disrupted unless with her family's own accord. or permision".

It is clear that Islam recognises women's rights, contradictory to the conditions during pre-Islamic era (jahiliah) where people did not recognise women's rights. In fact, they downgraded and disrespected women as described in surah al-Nahl verse 58-5923. During the Jahiliyyah's period, women were controlled by powerful people and they were traded just like goods. In fact, the society practised female infanticide as female infants were deemed as unlucky (Al-Mubarakfuri, 2011).

\section{The Principle of Justice}

The principle of justice aims to free human beings from cruelty and oppression (Mat \& Suradi, 2012). Justice which is implemented by Prophet Muhammad PBUH succeeds in creating sociopolitical stability in Medina (Siddiqi, 1982). This principle is Prophet Muhammad PBUH's goal in his struggle, as mentioned by Allah SWT which indicates:

"We have already sent Our messengers with clear evidences. We have sent down with them Scripture and justice scale so that people may maintain [their affairs] in justice". $\quad$ (Al-Hadid, 57:25)

"Allah SWT commands you to render trusts to whom they are due and when you judge between people, judge with justice. Excellent is that which Allah instructs you. Indeed, Allah is ever Hearing and Seeing".

(Al-Nisa', 4:58)

According to al-Qardhawi (1999), Allah SWT creates human being as a vicegrant so that he or she can deliver good deeds and avoid bad deeds. Therefore, Islam highlights the value of justice in human's life. ${ }^{24}$ According to Alatas (1996), social justice is an ultimate concept which is needed by countries in order to guarantee rights and interests of communities.

Hence, the Apostle of Allah has promulgated the Constitution of Medina based on the foundation of justice. For instance, Clause 21 argues the act of killing without strong evidences and it should be punished within the jurisdiction of qisas ${ }^{25}$, with the exception that his or her rightful owner/family agrees to accept diat ${ }^{26}$. Qisas and diat aim to protect human's right to live, besides establishing harmony and peace (Ibrahim \& El-Qasimy, 1985). Clause 21 states that:

\footnotetext{
${ }^{23}$ As mentioned by Allah SWT, which means:
}

"When one of them receives a news of female newborn, his face blackens or reddens and he will be in agony. He isolates himself from society because of the bad news. He will take care of his daughter and live in shame or he will burry her alive. Please know that they make a bad decision".

\footnotetext{
${ }^{24}$ Responsibility as a virtue is revealed in the Quran. Among them are surah al-Nisa' verse 3, 58, 129 and 135, al-Ma' 'idat verse 8 and 42, al-Mumtahanah verse 8, al-Baqarat verse 282 and 283, al-Hujurat verse 9 and 10, al-Nahl verse 90, Hud verse 85, al-A raf verse 29, ar-Rahman verse 9 and al-Syura verse 15 .
}

25 Punishment of Qias to offenders is equal to the offenses towards their victims. For instance, murders will receive death sentence (Ibrahim \& ElQasimy, 1985). Allah SWT mentions in surah al-Ma'idat verse 45 which indicates:

\footnotetext{
"And We have ordained for them in the scripture of Torah that, therein a life for a life, an eye for an eye, a nose for a nose, an ear for an ear, a tooth for a tooth, and for wounds is legal retribution. However, whoever gives [up his right as] charity, it is an expiation for him and whoever does not judge by what Allah has revealed, then, it is those who are the wrongdoers".
}

26 Diat is a fine which is compulsory to be paid fo criminal offenses as a substitute for Qias (Ibrahim \& El-Qasimy, 1985). 
"Those who murder without any legal evidence, should be punished with a death sentence unless the rightful owner/family agrees to receive blood money as a compensation. Mu'min should unite to condemn the act and they should upheld justice".

Similarly, the principle is highlighted in Clause 22 which clarifies every member of society is responsible to avoid giving any help and protection to those who are guilty of wrong doings. Anyone who offers protection to offenders will be deemed guilty as well and he or she will receive punishment in the hereafter as Allah SWT disgraces this kind of act. In fact, any compensation to escape from punishment will not be accepted. Clause 22 mentions that:

"Those who profess the contents of the treaty and those who believe in Allah SWT should never offer any help and protection to any wrong doer. Those who help any wrong doer, Allah SWT will curse them on the day of judgement or the hereafter. Any compensation and repentence will not be accepted".

The clause portrays justice and the fact that laws are fully recognised. Yaacob (1986) suggests that, Medinans have the rights to receive legal protection and justice as written in Clause 36 (b) and 47. Clause 36 (b) which discusses that punishment should be executed for every offense made despite position or status. Punishment will be executed to one's self and one's family. However, those who have been wronged will not receive any punishment. Clause 36 (b) states that:

"Punishment should not be prohibited for any injury caused upon an individual by anyone. Those who have commited any offense will be punished and the punishemnt will also be given to family members except those who have been wronged. Allah SWT will protect those who respect the treaty".

Clause 47 claims:

"The constitution or the treaty cannot be manipulated in order to protect those who are wicked and guilty. From this day onwards, the security of those who migrate to Medina or who reside in Medina will be guaranteed except for those who commit any offense. Allah SWT blesses those who do charity and those righteous who profess that Prophet Muhammad PBUH is His Messenger".

Additionally, the same priciple can also be seen in Clause 37 (b) which explains that anyone will not be punished for other individual's faults. Someone who is guilty should be responsible while an individual who has been wronged, should be given help accordingly (Ibrahim \& El-Qasimy, 1985). Clause 37 (b) states that:

"Any individual cannot be considered guilty for the faults of his or her affiliates and help should be given to those who are mistreated".

These Clauses ascertain that the Apostle of Allah implements justice within every community in Medina, regardless of social difference or status. This principle is used to create social balance for the sake of establishing a peaceful and harmonious country. According to Maududi (1986), the rights of both Muslims and non-Muslims are protected under Islamic ruling.

\section{The Principle of Responsibility}

Islam outlines responsibility to every Muslim to implement Islamic shari'a especially justice for the sake of everyone's well being (Ali \& Zuhdi, t.t.). Hence, responsibility 
is essential to develop individual, society and country. Therefore, the Apostle of Allah stipulates responsibilities to every member of the communities in Medina (Sidik, 2004). This is to make sure that the plural society can cooperate together in safeguarding Medina so that it stays peaceful, as mentioned by Majid that: ${ }^{27}$

"Prophet Muhammad PBUH does not neglect or downgrade differences and racial diversity. He ordains responsibilities to all communities in Medina so that they can cooperate together to keep Medina peaceful".

In short, plural society has roles and responsibilities which need to be put into action. According to Al-Bakri, the Constitution of Medina thoroughly describes responsibilities of societies in Medina. ${ }^{28}$ For instance, those Muhajirin from the tribe of Quraisy have their own original custom, which is to pay and to receive blood money/ransom mutually among them in a good way and with fairness. This is described in Clause 3:

"Those Muhajirin from Quraisy follow their old custom. They will mutually support the cost and accept compensation's money (diat) within their community for the sake of compensating those who are captivated by ways of giving charity and upholding justice among the belivers".

Tribes from Medina, Bani Auf, Bani al-Harith, Bani Sa'idah, Bani Jusyam, Bani al-Najjar, Bani 'Amru bin 'Auf, Bani al-Nabiet and Bani Aus are mutually responsible to support the cost of war including to pay and to receive blood money/ransom for those who are captivated, in good term and justice. Responsibilities of these tribes are stated in Clause 4, 5, 6, 7, 8, 9, 10 and 11 . In contrast, Clause 12 substantiates responsibilities of Muslims to provide financial support in terms of paying blood money/ransom, fairly. Clause 12 mentions that:

"Believers cannot let any problem occurs between them and they should be responsible in giving contributions towards the cost of blood money and they should do everything with justice".

Apart from that, Muslims and non-Muslims are responsible in defending Medina and providing financial support to the country, as mentioned in Clause 24, 37 and 38. Among the responsibilities are, financing the cost of war, providing contributions of wealth and weapon as well as cooperating with Muslims in defending Medina (Noh, 2001; Sidik, 2004; Yaacob, 1986). Those clauses are:

Clause 24:

"Jews and Muslims should mutually provide financial help when they are still at war".

Clause 37:

"Jews should provide financial support for the country and they should offer help in protecting members of the treaty from any attack by enemies. They should also give advice to each other and provide charity towards any sinful act".

Clause 38:

"Jews and Muslims should mutually give financial support when they involve in any battle".

\footnotetext{
${ }^{27}$ Interview with Majid at Department of Fiqh and Usul Fiqh, Kulliyyah Islamic Revealed Knowledge and Human Sciences, UIAM, Gombak on 30 January 2013.

${ }^{28}$ Interview with Al-Bakri at Pejabat Pustaka Cahaya Kasturi, Putra Nilai, Nilai, Negeri Sembilan on 29 January 2013.
} 
On the other hand, Sidik (2004) justifies that, members of the society should be responsible to participate in every peace treaty as written in Clause 45 (b) and 46 . Clause 45 (b) states that:

"It is obligatory for every party to take part in any peace treaty".

Meanwhile, Clause 46 emphasises that:

"Jews of Aus and everyone who support them should carry out similar obligations which are mutual to other parties that are included in the treaty for the sake of ensuring peace and harmony within every party involved in the treaty. They should offer charity and avoid doing any sinful thing as everyone is responsible for his or her own doings. Allah SWT approves the truthful contents of the treaty and He has given His blessings".

Clearly, these clauses portray that the Constitution of Medina encourages the value of being responsible. The Apostle of Allah, PBUH prescribes responsibility towards members of the society so that they cooperate with each other to ensure that Medina is peaceful from any threat. As a result, Medina becomes the symbol of Islamic strenght and the ultimate Islamic defense system in order to face threats from four major power which are, Rome, Persian, Arab tribes from Arabian Peninsula and Makkan's Quraish infidels (Ramadhan, 1991).

\section{Conclusion}

The Medina Charter has successfully eliminated the division of racial and the tribal system that destroys the system of society. Prophet Muhammad PBUH has succeeded to manage the plural society in Madinah by laying the principle of tolerance, love, respect, justice and responsibility in the Charter of the Medina. These principles have played a role in unifying and building cooperative relationships in the plural society and becoming the fortress of the Medina. Therefore, the plural society has become a symbol of strength and success in Medina.

However, this practice is in contrast with the Plural Society Theory by Furnivall (1956) which states that the plural society is characterized by fights and conflicts even in the same political unit. Compound society exists in various parts of the community but lives separately. This community of various ethnics actually exists on the basis of tension and no mutual value.

Hence, this theory is contrary to the plural society in the time of Prophet Muhammad PBUH that has a harmonious relationship. The plural society can be well managed if the basic principles of society are given priority. The plural community management by Prophet Muhammad PBUH is the best example that can be used as a guide.

\section{References}

Ahmad, Z. A. (1973). Piagam Nabi Muhammad SAW: Konstitusi Negara Bertulis Pertama di Dunia. Jakarta: Bulan Bintang.

Al-Buti, M. S. R. (1997). Fiqh Al-Sirah Jilid 2 (Terj. Mohd. Darus Sanawi ‘Ali). Shah Alam: Dewan Pustaka Fajar. 
INTERNATIONAL JOURNAL OF ACADEMIC RESEARCH IN BUSINESS AND SOCIAL SCIENCES

Vol. 8, No. 12, Dec, 2018, E-ISSN: 2222-6990 C 2018 HRMARS

Al-Ghazaliy, M. (1997). Fiqhus Sirah: Menghayati Nilai-Nilai Riwayat Hidup Muhammad Rasulullah SAW (Terj. Abu Laila \& Muhammad Tohir). Klang: Klang Book Centre.

Al-Ghazaliy, M. (1997). Fiqhus Sirah: Menghayati Nilai-Nilai Riwayat Hidup Muhammad Rasulullah SAW (Terj. Abu Laila \& Muhammad Tohir). Klang: Klang Book Centre.

Al-Hamidi, M. A. (2006). Sirah Nabawiyah: Muhammad for the Global Village (Terj. Zulfakar Ali \& Alimin Kuto Al-Madjid). Jakarta: Rabitha Press.

Ali, S. A. H. (1982). Muhammad Rasulullah. The Apostle of Mercy (Terj. Mohiuddin Ahmad). Lucknow, India: Academy of Islamic Research \& Publications.

Al-Mubarakfuri, S. S. A. (2011). Sirah Rasulullah SAW (Terj. Mohd Darus Senawi Ali: Al-Raheeq AlMakhtum). Selangor: Crescent News (K.L) \& Kumpulan Usahawan Muslim.

Al-Siba'ei, M. (1985). Al-Sirah Al-Nabawiyyah (Terj. Nabhan Hussin: Al-Sirah Al-Nabawiyyah Durus Wa'ibar). Shah Alam: Dewan Pustaka Fajar.

An-Nadwy, A. H. A. (1983). Riwayat Hidup Rasulullah SAW (Terj. Bey Ariffin \& Yunus Ali Muhdhar). Singapura: Pustaka Nasional.

Baharuddin, S. A. (Ed.) (2007). Modul Hubungan Etnik. Putrajaya: Universiti Teknologi Mara (UPENA).

Barakat, A. (1979). Muhammad and the Jews. New Delhi: Vikas Publishing House.

Bukhary, A (2009). Terjemahan Hadis Shahih Bukhari Jilid I, II, III \& IV (Terj. H. Zainuddin Hamidy et al.). Kuala Lumpur: Klang Book Centre.

Che Mat, C. B. et al. (2007). Pengenalan kepada Sistem Kemasyarakatan dan Kenegaraan Islam. Shah Alam: Pusat Penerbitan Universiti (UPENA).

Embong. Z. (2016). Ta'awun Piagam Madinah Dalam Pembangunan Komuniti Majmuk di Kawasan Rukun Tetangga Timur Laut dan Barat Daya, Pulau Pinang. Tesis Doktor Falsafah. Universiti Sains Malaysia. Tidak diterbitkan.

Furnivall, J. S. (1956). Colonial Policy and Practice: A Comparative Study of Burma and Netherlands India. New York: New York University Press.

Guillaume, A. (2004). The Life of Muhammad. Karachi: Oxford University Press.

Hamidullah, M. (1968). The Muslim Conduct of the State. Lahore: Ashraf.

Hamka (Haji AbdulMalik AbdulKarim Amrullah) (1985). Tafsir Al-Azhar Juzu' 10-11-12. Jakarta: Pustaka Panjimas. 
INTERNATIONAL JOURNAL OF ACADEMIC RESEARCH IN BUSINESS AND SOCIAL SCIENCES

Vol. 8, No. 12, Dec, 2018, E-ISSN: 2222-6990 C 2018 HRMARS

Hussin, Z. (2003). Konsep Tasamuh Menurut Perspektif Islam dan Sejarah Penghayatannya. Tesis Sarjana, Universiti Sains Malaysia. Tidak diterbitkan.

Ibrahim, A. \& El-Qasimy, D. (1985). Piagam Madinah: Pandangan dan Ulasan (Terj. Abu Bakar Hamzah). Kuala Lumpur: Gelanggang Kreatif.

Ishaq, I. (1970). Sirat Rasulullah (Terj. Alfred Guillaume: TheLife of Muhammad). Lahore: Oxford University Press.

Izzuddin, (2008). Konsep Ummah dalam Piagam Madinah. Jurnal Darussalam, 7(2), 109-122.

Khairuddin, A. (2007). Konstitusi Madinah Latar Belakang dan Dampak Sosialnya. Al-Banjari, 5(9), 120.

Khaldun, I. (1993). Mukadimah Ibn Khaldun (Terj. Dewan Bahasa dan Pustaka). Kuala Lumpur: Dewan Bahasa dan Pustaka.

Peters, F. E. (1994). Muhammad and the Origins of Islam. New York: State University of New York Press.

Pulungan, J. S. (1993). Prinsip-Prinsip dalam Perlembagaan Madinah ditinjau dari Pandangan AlQur'an. Disertasi Doktor Falsafah, IAIN Syarif Hidayatullah Jakarta.

Rahman, A. (1992). Ensiklopedia Sirah, Sunah, Dakwah dan Islam Jilid 1(Terj. Zaharah Salleh: Muhammad S.A.W. Encyclopaedia of Seerah, Volume 1). Kuala Lumpur: Dewan Bahasa dan Pustaka.

Rahman, M. S. A. (1995). Kedudukan Masyarakat Bukan Islam dalam Sejarah Pemerintahan Islam. DIm. Pemerintahan Islam dalam Masyarakat Majmuk. Kuala Lumpur: Institut Kefahaman Islam Malaysia.

Ramadhan, M. (1991). Inti sari Seerah Muhammad bin Abdullah SAW. Kuala Lumpur: A.S Noordeen. Siddiqi, N. (1982). Muhammad Membentuk Ummah (Terj. Mustaffa Ramadhan: Muhammad the Benefactory of Humanity). Pulau Pinang: Concentration Book Centre.

Sosrodirdjo, H. R. M. (1988). Ensiklopedia Istilah Agama Islam. Kuala Lumpur: Golden Books Centre.

Sungib, S. (2013). Rahsia-Rahsia Besar disebalik Sirah Rasulullah SAW. Selangor: Kemilau Publika.

Watt, W. M. (1956). Muhammad at Medina. London: Oxford University Press. 
INTERNATIONAL JOURNAL OF ACADEMIC RESEARCH IN BUSINESS AND SOCIAL SCIENCES

Vol. 8, No. 12, Dec, 2018, E-ISSN: 2222-6990 C 2018 HRMARS

Yaacob, A. M. (1986). Hak Asasi Manusia Menurut Islam: Sejarah dan Konsepnya. Bangi: Universiti Kebangsaan Malaysia.

List of Interviews

Interview with Majid, M. Z. A. at Department of Fiqh and Usul Fiqh, Faculty of Islamic Revealed Knowledge and Human Sciences, UIAM, Gombak on 30 January 2013, at 11.30 a.m.

Interview with Al-Bakri, Z. M. at Pejabat Pustaka Cahaya Kasturi, Putra Nilai, Nilai, Negeri Sembilan on 29 January 2013, at 9.30 a.m.

Interview with Abidin, D. Z. di Klinik Syifa', Pulau Pinang on 17 September 2015, at 6.00 p.m.

\section{Corresponding Author}

Zaleha Embong

Center for Language Studies and Generic Development (PBI)

Universiti Malaysia Kelantan, 16300, Bachok, Kelantan, MALAYSIA

Email: zaleha.e@umk.edu.my 